UDK 539.3:517.3+624.042.044

O.B. Kozin ${ }^{1}$, PhD, Assoc.Prof., O.B. Papkovskaya ${ }^{2}, \mathrm{PhD}$, Assoc.Prof.

${ }^{1}$ National University “Odesa Law Academy”, 23 Fontans'ka Rd., 65009 Odessa, Ukraine; e-mail: kozindre@rambler.ru

${ }^{2}$ Odessa National Polytechnic University, 1 Shevchenko Ave., 65044 Odessa, Ukraine

\title{
ANALYSIS OF STRESS-STRAIN STATE OF THE SPHERICAL SHALLOW SHELL WITH INCLUSION
}

О.Б. Козін, О.Б. Папковська. Аналіз напружено-деформованого стану сферичної пологої оболонки 3 включенням. Розробка ефективних методів визначення напружено-деформованого стану конструкцій з тонкостінними включеннями, підкріпленнями та іншими концентраторами напружень є важливим завданням як з теоретичної, так і з практичної точки зору, зважаючи на їх велике практичне застосування. Мета: Метою роботи є аналіз напружено-деформованого стану сферичної пологої оболонки. Mатеріали і методи: У роботі на основі узагальненої схеми інтегральних перетворень запропоновано конструктивний метод прямого чисельно-аналітичного розв'язання крайової задачі розрахунку напружено-деформованого стану сферичної пологої оболонки 3 включенням при вигині. Результати: Представлено результати чисельних розрахунків. Розрахунки дозволяють спрогнозувати величину деформації конструкцій у вигляді циліндричних оболонок з підкріпленнями і визначити ії оптимальні параметри при проектуванні або у виробництві. Отримані результати можуть бути використані при визначенні характеристик міцності структурних елементів, що складаються з композиційних матеріалів. Стаття містить порівняльний аналіз результатів і демонструє ефективність методу при вирішенні даного класу задач.

Ключові слова: крайова задача, напружено-деформований стан, полога оболонка, жорстке включення, вигин, поліном Якобі.

O.B. Kozin, O.B. Papkovskaya. Analysis of stress-strain state of the spherical shallow shell with inclusion. Development of effective methods of determining the stress-strain state thin-walled structures with inclusions, reinforcements and other stress concentrators is an important task, both from a theoretical and practical point of view, by reason of their great practical application. Aim: The aim of the research is to analyze the elastic-deformed state of a spherical shallow shell. Materials and Methods: In this work, based on the generalized scheme of integral transformations, a constructive method of direct numerical-analytical solutions of boundary value problem of calculating the stress-strain state of a spherical shallow shell with the inclusion in bending is proposed. Results: The results of numerical calculations are presented. Calculations allow predicting the value of deformation of the cylindrical shells structure with reinforcements and determining the optimum parameters for the design or manufacture. The obtained results can be used in determining the strength characteristics of structural elements that consist of composite materials. The article contains comparative analysis of the results and demonstrates the effectiveness of the method for solving this class of problems.

Keywords: boundary value problem, stress-strain state, shallow shell, rigid inclusion, bending, Jacobi polynomial.

Introduction. When creating calculation methods of the various constituent elements of the structures there is a need to study the interaction between the matrix and reinforcing fibers, studying the effect of geometry of the fibers, etc. The presence of the reinforcing fibers, the ribs and other irregularities significantly complicates the calculation, since these elements are stress concentrators. Therefore, the development of effective methods of determining the stress strain state structures with stress concentrators of this kind is an important problem from both a theoretical and practical point of view.

Boundary element method is an efficient way to solve partial differential equations of boundary value problems. Numerical methods based on boundary integral equations are powerful tools in many areas of engineering and science including theory of orthotropic plates [1], anisotropic plates [2] with cracks and thin rigid inclusions. Application of the singular integrated equations to the solving of a number of technological tasks is considered in [3]. The mathematical model which allows controlling a condition of hereditary defects like exfoliation on border of the main material and a covering is also developed in [3].

The resulting numerical methods have usually highly accurate, but require deep analysis, refined algorithms, and high performance computing to make them competitive in applications.

One of the methods for solving a lot of class of boundary value problems is the numericalanalytical method of generalized integral transformations [4...10]. This method is one of the branches 
of the boundary element method. It does not require high-power for high-performance computing. This method is based on reducing problem to the system of integral equations with respect to singularity of these equations.

Analysis of the thermal conductivity of plates with internal S-figurative heat sources was considered in $[4,5]$. The method was further developed for solving the problems of bending orthotropic plates with linear inhomogeneities, oriented arbitrarily. The exact solution of the problem of bending of an infinite shallow shell in the presence of a semi-infinite Winkler support by reduction to the Riemann problem was obtained in [8]. Problem of bending of a shallow shell with the inclusion was reduced to a system of integral equations [9].

In [10] was carried out further development and detailing of the method of solving the problems of bending cylindrical shallow shells with thin rigid linear inclusions. Namely, the numerical solution of the boundary value problem of bending a cylindrical shallow shell with inclusion parallel to the main meridian curvature has been obtained.

The aim of the article is to analyze the elastic-deformed state of a spherical shallow shell, not considered in [10]. The practical significance is the proposed method and the numerical results which allow to predict the value of deformation of the cylindrical shells structure with reinforcements and to determine the optimum parameters for the design or manufacture.

Materials and Methods. In research [9], the problem of bending simply supported shallow shell with rectangular profile $(0 \leq x \leq a, 0 \leq y \leq b)$ and a thin rigid inclusion located on the segment $y=b / 2 \equiv l$, $c \leq x \leq d(0<c<d<a)$ was reduced to a system of integral equations:

$$
\begin{gathered}
\frac{-2 c_{1}}{a E h} \int_{c}^{d} X_{6}(t) \sum_{n=1}^{\infty} \sin \left(\alpha_{n} t\right) \sin \left(\alpha_{n} x\right) \mathfrak{x}_{1 n} d t+\int_{c}^{d} \Psi(t) \sum_{n=1}^{\infty} \sin \left(\alpha_{n} t\right) \sin \left(\alpha_{n} x\right) \mathfrak{x}_{2 n} d t=\omega^{*}(x), \\
\frac{-2}{a} \int_{c}^{d} X_{6}(t) \sum_{n=1}^{\infty} \sin \left(\alpha_{n} t\right) \sin \left(\alpha_{n} x\right) \mathfrak{x}_{3 n} d t+\int_{c}^{d} \Psi(t) \sum_{n=1}^{\infty} \sin \left(\alpha_{n} t\right) \sin \left(\alpha_{n} x\right) \mathfrak{x}_{4 n} d t=0 .
\end{gathered}
$$

Here $\alpha_{n}=\pi n / a, X_{6}(t), \Psi(t)$ - unknown functions. Other characters are constants which do not depend on $n \cdot \omega^{*}(x)$ - known function, $x \in[c ; d]$.

The functions $\mathfrak{1}_{1 n}, \mathfrak{2}_{2 n}, \mathfrak{x}_{3 n}, \mathfrak{x}_{4 n}$ have the following asymptotic estimates:

$$
\mathfrak{x}_{1 n}=O\left(\alpha_{n}{ }^{-3}\right), \mathfrak{x}_{2 n}=O\left(\alpha_{n}{ }^{-3}\right), \mathfrak{x}_{3 n}=O\left(\alpha_{n}\right), \mathfrak{x}_{4 n}=O\left(\alpha_{n}{ }^{-3}\right) \text { as } \alpha_{n} \rightarrow \infty .
$$

Using (2), we can rewrite the system (1) with a separated singular part:

$$
\begin{gathered}
A_{1} \int_{c}^{d} X_{6}(t)\left[(x-t)^{2} \ln |x-t|+K_{11}(x, t)\right] d t+A_{2} \int_{c}^{d} \Psi(t)\left[(x-t)^{2} \ln |x-t|+K_{12}(x, t)\right] d t=\omega^{*}(x), \\
A_{3} \frac{d^{2}}{d x^{2}} \int_{c}^{d} X_{6}(t)\left[\ln |x-t|+K_{21}(x, t)\right] d t+A_{4} \int_{c}^{d} \Psi(t)\left[(x-t)^{2} \ln |x-t|+K_{22}(x, t)\right] d t=0,
\end{gathered}
$$

where $K_{i j}(x, t)(i=1,2 ; j=1,2)$ is infinitely differentiable functions; $A_{1} \ldots A_{4}$ - known constants.

Assume, that inclusion located symmetrically with respect to the line $x=a / 2$ and the external load is applied symmetrically with respect to this line. Reducing the integration interval and interval for $x$ to the segment $[-1,1]$, from (1) we obtain:

$$
\begin{gathered}
\pi^{2} H \varepsilon \int_{-1}^{1} X_{R}(\tau) \sum_{k=0}^{\infty} \frac{\cos \left(\sigma_{k} \tau\right) \mathfrak{x}_{5 k}}{\cos ^{-1}\left(\sigma_{k} z\right)(2 k+1)} d \tau-\int_{-1}^{1} \Psi_{R}(\tau) \sum_{k=0}^{\infty} \frac{\cos \left(\sigma_{k} \tau\right) \mathfrak{x}_{6 k}}{\cos ^{-1}\left(\sigma_{k} z\right)(2 k+1)^{3}} d \tau=\frac{W_{0} \pi^{3}}{a^{2} D^{-1},} \\
\pi^{2} H \varepsilon \int_{-1}^{1} X_{R}(\tau) \sum_{k=0}^{\infty} \frac{\cos \left(\sigma_{k} \tau\right) \mathfrak{x}_{7 k}}{\cos ^{-1}\left(\sigma_{k} z\right)(2 k+1)} d \tau-\int_{-1}^{1} \Psi_{R}(\tau) \sum_{k=0}^{\infty} \frac{\cos \left(\sigma_{k} \tau\right) \mathfrak{x}_{8 k}}{\cos ^{-1}\left(\sigma_{k} z\right)(2 k+1)} d \tau=0,
\end{gathered}
$$

where $\sigma_{k}=\pi(2 k+1)(d-c) /(2 a), X_{R}(\tau), \Psi(\tau)$ - unknown functions,

$$
\mathfrak{x}_{5 n}=O(1), \mathfrak{x}_{6 n}=O(1), \mathfrak{x}_{7 n}=O(1), \mathfrak{x}_{8 n}=O(1) \text { as } \alpha_{n} \rightarrow \infty .
$$


Other characters are constants which do not depend on $n$. Variable $z \in[-1 ; 1]$.

This system will be solved numerically, applying an approximate numerical-analytical orthogonal polynomials method [6]. Based on the asymptotic estimates (4), the unknown functions of (3) are searching in the form of series:

$$
\Psi_{R}(\tau)=\sum_{j=0}^{\infty} \psi_{j} p_{j}(\tau) ; X_{R}(\tau)=\sum_{j=0}^{\infty} \chi_{j} R_{j}(\tau),
$$

where $\quad p_{0}(\tau)=\left(1-\tau^{2}\right)^{-1 / 2} ; \quad p_{j}(\tau)=\frac{2(2 j) ! \sqrt{\pi} P_{2 j}^{-3 / 2,-3 / 2}(\tau)}{\Gamma(2 j-1 / 2)\left(1-\tau^{2}\right)^{3 / 2}} ; \quad(j=\overline{1, \infty}) ; R_{j}(\tau)=\sqrt{1-\tau^{2}} U_{2 j}(\tau)$;

$P_{j}^{\alpha, \beta}(\tau)$ - Jacobi polynomials;

$U_{j}(\tau)$ - Chebyshev polynomials of the second kind;

$\psi_{j}, \chi_{j}$ - the unknown constants.

The choice of these polynomials according to the method of orthogonal polynomials, defined by the presence of relations 4.4, 4.5, 4.6 [6], called spectral. Using these relations, the corresponding integrals can be easily calculated:

$$
\int_{-1}^{1} \frac{p_{j}(\tau) d \tau}{\pi b \sec b \tau}=\frac{J_{2 j-1}(b)}{(-1)^{j}}, \int_{-1}^{1} \frac{p_{0}(\tau) d \tau}{\pi \sec b \tau}=J_{0}(b), \int_{-1}^{1} \frac{R_{j}(\tau) d \tau}{\sec b \tau}=\frac{\pi \Gamma(2+2 j) J_{1-2 j}(b)}{(-1)^{j}(2 j) ! b}, j=\overline{1, \infty}
$$

Here $\sec b \tau=1 / \cos b \tau ; \quad J_{2 j-1}(b)-$ Bessel function of the first kind; $\Gamma_{j}(b)-$ gamma function.

As it follows from (5), the solutions $p_{m}(z)$ are searching in the space of functions, which have nonintegrable singularities; therefore we will use the apparatus of the regularization of divergent integrals [6].

Substituting (5) into (3), multiplying the first equation of system (1) by $p_{m}(z)$, the second - by $R_{m}(z)$, integrating both sides with respect to $z$ from -1 to 1 and taking into account formulas B 4.4, B 4.5, B 4.6, obtained in [6], we obtain an infinite system of linear algebraic equations with respect to the unknowns $\chi_{j}$ and $\psi_{j}[10]$.

$$
\begin{gathered}
\sum_{j=0}^{\infty} \chi_{j} e_{m j}+\sum_{j=0}^{\infty} \psi_{j} c_{m j}=-W_{0} \pi^{2} a^{-2} D \delta_{0 m} \equiv f_{m},(m=\overline{0, \infty}), \\
\sum_{j=0}^{\infty} \chi_{j} h_{m j}+\sum_{j=0}^{\infty} \psi_{j} s_{m j}=0,(m=\overline{0, \infty}),
\end{gathered}
$$

where

$$
\begin{gathered}
c_{00}=\sum_{k=0}^{\infty} J_{0}^{2}(\sigma) \frac{\mathfrak{x}_{6 k}}{(2 k+1)^{3}}, c_{0 j}=c_{j 0}=(-1)^{j} \sum_{k=0}^{\infty} \sigma_{k} J_{0}\left(\sigma_{k}\right) J_{2 j-1}\left(\sigma_{k}\right) \frac{\mathfrak{x}_{6 k}}{(2 k+1)^{3}}, \quad(j \geq 1), \\
c_{m j}=(-1)^{m+j} \sum_{k=0}^{\infty} \sigma_{k}^{2} J_{2 j-1}\left(\sigma_{k}\right) J_{2 j-1}\left(\sigma_{k}\right) \frac{\mathfrak{x}_{6 k}}{(2 k+1)^{3}}, \quad(m, j \geq 1), \\
e_{0 j}=e_{j 0}=\frac{\varepsilon H \pi^{2}}{(-1)^{j+1}(2 j+1)^{-1}} \sum_{k=0}^{\infty} J_{0}(\sigma) J_{2 j+1}(\sigma) \sigma^{-1} \frac{\mathfrak{x}_{5 k}}{(2 k+1)}, \quad(j \geq 0), \\
e_{m j}=\frac{\varepsilon H(2 j+1)}{\pi^{-2}(-1)^{m+j+1}} \sum_{k=0}^{\infty} J_{2 m+1}\left(\sigma_{k}\right) J_{2 j+1}\left(\sigma_{k}\right) \sigma_{k}^{-1} \frac{\mathfrak{x}_{5 k}}{(2 k+1)},(m \geq 1, j \geq 0), \\
S_{m 0}==(-1)^{m}(2 m+1) \sum_{k=0}^{\infty} J_{0}\left(\sigma_{k}\right) J_{2 m+1}\left(\sigma_{k}\right) \sigma_{k}{ }^{-1} \frac{\mathfrak{x}_{8 k}}{(2 k+1)}, \quad(m \geq 0),
\end{gathered}
$$




$$
\begin{gathered}
S_{m j}=(-1)^{m+j}(2 m+1) \sum_{k=0}^{\infty} J_{2 m+1}\left(\sigma_{k}\right) J_{2 j+1}\left(\sigma_{k}\right) \frac{\mathfrak{x}_{8 k}}{(2 k+1)}, \quad(m \geq 0, j \geq 1), \\
h_{m j}=\frac{\varepsilon H(2 j+1)(2 m+1)}{\pi^{-2}(-1)^{m+j+1}} \sum_{k=0}^{\infty} J_{2 m+1}\left(\sigma_{k}\right) J_{2 j+1}\left(\sigma_{k}\right) \sigma_{k}^{-2}(2 k+1) \mathfrak{x}_{7 k}, \quad(m \geq 0, j \geq 0) .
\end{gathered}
$$

Equilibrium conditions for inclusion are

$$
\int_{c_{1}}^{d}<S(x, l)>d x=0 ; \int_{c_{1}}^{d} \Psi(\xi) d \xi=P .
$$

where $P$ - the main vector of forces applied to the inclusion in point $(a / 2, b / 2), \quad\langle S(x, l)\rangle-$ differences of the tangential forces and $\Psi(\xi)$ - differences of the generalized transverse forces when passing through the inclusion. The first condition in (7) is satisfied identically due to the symmetry of the problem, the second condition of (7), taking into account (5) gives:

$$
\frac{1}{2} \int_{-1}^{1} \Psi_{R}(\xi) d \xi=\frac{1}{2} \sum_{j=1}^{\infty} \psi_{j} \int_{-1}^{1} p_{j}(\tau) d \tau=\frac{\pi}{2} \psi_{0}=P
$$

As it can be seen from (6), the required coefficients $\chi_{j}$ and $\psi_{j}$ are proportional to values $W_{0} D a^{-2}$, i.e. $\chi_{j}=\psi_{j}=\tilde{\alpha} D W_{0} a^{-2},(j=\overline{0, \infty})$. Thus, solving the system of (6), with its right-hand side equal to $-\pi^{2} \delta_{0 m}, m=\overline{0, \infty}$. Value of flexure $W_{0}$ we finding from the condition of equilibrium of the inclusion (7), using $W_{0}=a^{2} D^{-1} 2 P \pi^{-1} \tilde{\alpha}_{0}^{-1}=a^{2} D^{-1} P \alpha$, where $D$ is the bending stiffness of the spherical shell.

System (6) has been calculated numerically by method of reduction. In the formula

$$
W_{0}=10^{-3} \mathrm{~Pa}^{2} \mathrm{D}^{-1} \alpha,
$$

the non-dimensional coefficient $\alpha=\alpha\left(\bar{R}_{1}, \bar{R}_{2}, \lambda, \varepsilon\right)$ was calculated, where $\bar{R}_{1}=a^{2} /\left(h R_{1}\right)$, $\bar{R}_{2}=a^{2} /\left(h R_{2}\right), \lambda=a / b, \varepsilon=\left(d-c_{1}\right) / a, R_{1}=R_{2}, \alpha=2 \pi^{-1} \psi_{0}^{-1} . R_{1}$ - curvature of the shell in the direction $x, R_{2}$ - curvature of the shell in the direction $y, h$ - shell thickness, $\tilde{\psi}_{0}$ - zero coefficient of series for $\Psi_{R}(\tau)$, which is found from the solution of system (6) with the right-side of this system is equal to $-\pi^{2} \delta_{0 m}, m=\overline{0, \infty}$. Poisson's coefficient $v$ was assumed to be equal $1 / 3$.

Results and Discussion. The boundary value problem is reduced to the infinite system of linear algebraic equations, which is solved numerically by method of reduction. Values of the nondimensional coefficient $\alpha$ are shown on the graph (Fig. 1).

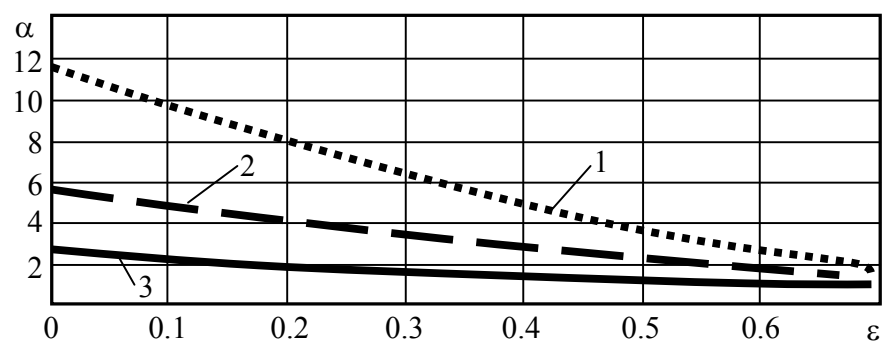

Fig. 1. Values of the coefficient $\alpha: \bar{R}_{1}=\bar{R}_{2}=0$ (1); $\bar{R}_{1}=\bar{R}_{2}=5$ (2); $\bar{R}_{1}=\bar{R}_{2}=10$ (3)

The results of this research were compared with the results of [10], where the deformation of shallow cylindrical shell with rigid inclusion located parallel to the main meridian curvature. 
Comparison of curves 2 and 3 with the results of [10] shows, that the rigidity of shallow spherical shells with the inclusion, for equal values of the dimensionless principal curvatures and other parameters, significantly higher than the rigidity of corresponding cylindrical shells with inclusion.

Namely, in the case of values of the non-dimension radius of curvature of the shell equal to $\bar{R}_{2}=5$ and non-dimension length of inclusion equal to $f=0.7$, bending of the inclusion of a cylindrical shell is 1.2 times greater than the corresponding bending of the inclusion of spherical shell. If the parameter $e=0.1\left(\bar{R}_{2}=5\right)$, then value of bending increases to 1.78 .

In the case of values of the non-dimension radius of the shell curvature equal to $\bar{R}_{2}=10$ and non-dimension length of inclusion equal to $f=0.7$, bending of the inclusion of a cylindrical shell is 2 times greater than the corresponding bending of the inclusion of spherical shell. If the parameter $e=0.1\left(\bar{R}_{2}=10\right)$, then value of bending increases to 2.8 .

Sufficient precision of calculations 0.001 was obtained while maintaining eight equations in the system (6), which shows the high efficiency of this method for solving this problem. Earlier, in $[6,12]$, in particular, bending in the center of free - simply supported rectangular plate was studied. The bending in the center has been represented as formula $W_{0}=P a^{2} D^{-1} \alpha$. Coefficient of proportionality $\alpha$ was calculated. Obtained result: $\alpha \approx 0.01160[6,12]$. This value coincides with the value of the coefficient $\alpha \cdot 10^{-3}$ in equation (9) shown in the graph (1). See the value of this graph at $\varepsilon=0$.

Thus, we have obtained the numerical-analytical solution of this boundary value problem. The relations of the bending of inclusion depending on his length and depending on geometric characteristics and mechanical properties of the spherical shell have been determined. Comparative analysis of the obtained results with previously published results has been performed.

\section{Література}

1. Сурьянинов, Н.Г. Приложение численно-аналитического метода граничных элементов к расчету ортотропных пластин / Н.Г. Сурьянинов, И.В. Павленко // Пр. Одес. політехн. ун-ту. — 2014. — Вип. 1(43). - С. $18-27$.

2. Максименко, В.Н. Напряженно-деформированное состояние анизотропной пластины, содержащей криволинейные трещины и тонкие жесткие включения / В.Н. Максименко, Е.Г. Подружин, П.Е. Рябчиков // Изв. РАН. Механика твердого тела. - 2007. - № 2. - С. 66 - 74.

3. Усов, А.В. Математическое моделирование процессов контроля покрытий элементов конструкций на базе сингулярных интегральных уравнений / А.В. Усов, А.А. Батырев // Пробл. машиностроения. - 2010. - Т. 13, № 1. - С. $65-75$.

4. Козин, А.Б. Метод моделирования и решения задач теплопроводности пластин с тонкостенными криволинейными и произвольно-ориентированными неоднородностями / А.Б. Козин, Г.А. Козина, О.Б. Папковская // Пр. Одес. політехн. ун-ту. - 1998. - Вип. 2(6). - С. 192 - 194.

5. Математическая модель теплопроводности в сложных дискретно-непрерывных конструкциях / А.Б. Козин, Л.А. Довнарович, И.А. Данилюк, О.Б. Папковская // Технология и конструирование в электронной аппаратуре. - 2004. - № 1. - С. $30-35$.

6. Попов, Г.Я. Концентрация упругих напряжений возле штампов, разрезов, тонких включений и подкреплений / Г.Я. Попов. - М.: Наука, 1982. - 342 с.

7. Папковская, О.Б. Математическая модель изгиба ортотропной пластины с криволинейной произвольно ориентированной неоднородностью / О.Б. Папковская, А.Б. Козин, Д. Камара // Пр. Одес. політехн. ун-ту. - 2008. - Вип. 1(29). - С. $237-241$.

8. Красный, Ю.П. Изгиб бесконечной пологой оболочки при наличии винклеровской полубесконечной опоры / Ю.П. Красный, А.Б. Козин, О.Б. Папковская // Науковий вісник Міжнародного гуманітарного університету. Серія: Інформаційні технології та управління проектами. — 2012. № 4. - C. $29-31$.

9. Козин, А.Б. О решении краевых задач изгиба композитных пологих оболочек / А.Б. Козин, О.Б. Папковская // Сб. науч. тр. SWorld: матер. междунар. науч.-практ. конф. «Перспективные инновации в науке, образовании, производстве и транспорте '2013», 17-26 дек. 2013 г., Одесса. 2013. - Т. 4: Физика и математика. - С. 33 - 37. 
10. Козин, А.Б. Напряженно-деформируемое состояние оболочки с включением при изгибе / А.Б. Козин, О.Б. Папковская // Пр. Одес. політехн. ун-ту. - 2014. - Вип. 2(44). - С. $15-20$.

11. Козин, А.Б. Приближенное решение одной системы интегральных уравнений / А.Б. Козин, О.Б. Папковская // Сб. науч. тр. SWorld: матер. междунар. науч.-практ. конф. «Научные исследования и их практическое применение. Современное состояние и пути развития '2014», 1-12 окт. 2014 г., Одесса. - 2014. - Т. 27. - С. $32-35$.

12. Timoshenk, S. Theory of plates and shells / S. Timoshenko, S. Woinowsky-Krieger. — New York: McGraw-Hill, 1959. - 580 p.

\section{References}

1. Suryaninov, N.G., \& Pavlenko, I.V. (2014). Application of numerical-analytical boundary element method to the calculation of orthotropic plates. Odes 'kyi Politechnichnyi Universytet. Pratsi, 1, 18 - 27. DOI:10.15276/opu.1.43.2014.04

2. Maksimenko, V.N., Podruzhin, E.G., \& Ryabchikov, P.E. (2007). Stress-strain state of an anisotropic plate with curved cracks and thin rigid inclusions. Mechanics of Solids, 42(2), 223 - 230. DOI:10.3103/S0025654407020070

3. Usov, A.V., \& Batyrev, A.A. (2010). Mathematical modeling of controlling the coating process of the structural elements based on singular integral equations. Journal of Mechanical Engineering, 13(1), 65 - 75.

4. Kozin, A.B., Kozina, G.A., \& Papkovskaya, O.B. (1998). Method of modeling and solution problems of heat conduction of plates with thin-walled and arbitrary-oriented heterogeneities. Odes'kyi Politechnichnyi Universytet. Pratsi, 2, $192-194$.

5. Kozin, A.B., Dovnarovich, L.A., Danilyuk, I.A., \& Papkovskaya, O.B. (2004). The mathematical model of heat conductivity in complex discrete-continuous design. Technology and Design in Electronic Equipment, 1, $30-35$.

6. Popov, G.Ya. (1982). Concentration of Elastic Stresses near Stamps, Cuts, Thin Inclusions and Reinforcements. Moscow: Nauka.

7. Papkovskaya, O.B., Kozin, O.B., \& Camara, D. (2008). Mathematical model of the flexion of orthotropic plate with curvilinear and arbitrarily oriented heterogeneity of structure. Odes 'kyi Politechnichnyi Universytet. Pratsi, 1, $237-241$.

8. Krasniy, J.P., Kozin, A.B., \& Papkovsky, O.B. (2012). Bend infinite shallow shell if Winkler semiinfinite supports. Herald of International Humanitarian University: Information Technologies and Project Management, 4, $29-31$.

9. Kozin, A.B., \& Papkovskaya, O.B. (2013). About solving boundary value problems of the bending composite shallow shells. In S.V. Kuprienko (Ed.), Proceedings of International Science and Practical Conference on Perspective Innovations in Science, Education, Production and Transport '2013 (pp. 33 37). Odessa: KUPRIENKO.

10. Kozin, A.B., \& Papkovskaya, O.B. (2014). Intensely deformed state of the shell with the inclusion in bending. Odes 'kyi Politechnichnyi Universytet. Pratsi, 2, 15 - 20. DOI:10.15276/opu.2.44.2014.04

11. Kozin, A.B., \& Papkovskaya, O.B. (2014). Approximate Solution of a System of Integral Equations. In S.V. Kuprienko (Ed.), Proceedings of International Science and Practical Conference "Scientific Researches and Their Practical Application. Modern State and Ways of Development '2014"'on (pp. 32 - 35). Odessa: KUPRIENKO.

12. Timoshenk, S., \& Woinowsky-Krieger, S. (1959). Theory of Plates and Shells. New York: McGrawHill. 